\title{
Evaluation of Structural and Mechanical Properties of the Nitrided Layer on Steel for Weapons
}

\author{
David Dobrocký1 ${ }^{1}$ Zdeněk Joska ${ }^{1}$, Jiř́ Procházka ${ }^{1}$, Emil Svoboda ${ }^{1}$, Petr Dostál ${ }^{2}$ \\ ${ }^{1}$ Faculty of Military Technology, University of Defence in Brno. Kounicova 65, 66210 Brno. Czech Republic. E- \\ mail: david.dobrocky@unob.cz, zdenek.joska@unob.cz,jiri.prochazka@unob.cz,emil.svoboda@unob.cz \\ ${ }^{2}$ Faculty of AgriSciences, Mendel University in Brno. Zemědělská 1, 61300 Brno. Czech Republic. E-mail: petr.do- \\ stal@mendelu.cz
}

Nitriding is a technology that leads to an increase in the utility value of the product. It's most important benefits include increased corrosion resistance, abrasion resistance, wear resistance, increased resistance to fatigue failure under cyclic loading, and many others. The design of a suitable nitriding technology not only on the basis of empirics requires a closer study of the relationship between the structure of the nitriding layer, its properties and the course of a particular degradation process. Because the life of most components is related to abrasion on the surface, the occurrence of fatigue cracks and corrosion effects, it is crucial to influence the mechanical and other properties in this surface area. High functional requirements are placed on the functional surfaces of steels for weapons production, which lead to a long service life, reliability and dependability of the components of the weapon system and its safe use. The paper discuss the influence of selected nitriding technologies on the mechanical properties of steel $42 \mathrm{CrMo} 4$ and 34CrNiMo6, especially on the hard and microhardness of surface layers, change of its structure and next to change the surface texture and dimension of component. The steels were nitrided in plasma and gas. Nitriding in gas led to more significant structural changes in the surface layer of both steels compared to plasma nitriding.

Keywords: Nitriding, Hardness, Microhardness, Texture, Dimension

\section{Introduction}

The life of most components and tools is related to abrasion on the surface, the occurrence of fatigue cracks and corrosion effects. All these influences begin to apply mainly from the surface of the part, and that is why it is crucial to influence the mechanical and other properties in this surface area [1], [2].

When choosing the type of material, it is almost always necessary to compromise, as the required operating properties are often more or less contradictory. The steel used in armaments production is often subject to conflicting requirements, related to the requirements for a high hardness of the wear-resistant surface layer and a tough core to carry dynamic loads. In addition to the optimal choice of material and its conventional heat treatment, traditional chemical-heat diffusion processes such as nitriding, carburizing and others have become very important in recent years [3], [4]. In particular, such processes can be considered optimal, which result in surface layers with good adhesion to the base material and during processing, as far as possible, the deformation of the components occurs minimally [5], [6].

The formation of a surface layer during nitriding is a diffusion process in which the atomic nitrogen for- med by the thermal dissociation of ammonia penetrates the surface of the saturated material. The course of the whole process can be intensified by the presence of an electrostatic field, glow discharge, etc. (plasma nitriding) or nitriding atmosphere at higher temperatures (gas nitriding) [7], [8], [9]. The purpose of the formed hard surface layer is primarily to increase the corrosion resistance, abrasion resistance, wear resistance and increase the fatigue resistance under cyclic loading [10]. Each of these purposes has different requirements to quality of the nitrided layer, suitable phase compositions are discussed eg in [11].

The basic property of a purely nitride layer - hardness, depends on the type and composition of the phases present (eg $\mathrm{Fe}_{4}(\mathrm{NC})$ ) has a hardness $\mathrm{HV} \sim 600$, but $(\mathrm{FeAl})_{4}(\mathrm{CN})$ to $\mathrm{HV} \sim 1200$. Further increases are brought by macroscopic internal stresses, caused by an increase in the volume (up to $5 \%$ ) of the white layer due to differences in the parameters of crystal lattices $a, \gamma^{\prime}$ and $\varepsilon$. Similar structural factors, increasing hardness, apply their effect to the basic mechanical characteristics - yield strength, strength and more [12]. These properties are used to increase the useful properties of parts of military equipment and technology. Examples are the nitriding of the inner cylindrical surfaces of the recuperator cylinder of the $152 \mathrm{~mm}$ howitzer brake device (ShKH vz. 77), nitriding of the bore of 
the main light machine gun FN Minimi (M249 SAW, $5.56 \mathrm{~mm}$ ) and nitriding of stators of jet engines of fighter aircraft Aero L-159 Alca .

This paper focuses on the structural and mechanical properties of nitrided layers in $42 \mathrm{CrMo} 4$ and $34 \mathrm{Cr}-$ NiMo6 steels, which are used in arms production (production of barrels, breech-blocks and closing mechanisms, crankshafts, gears, etc.). Samples of these steels were nitrided in plasma and gas in order to ensure identical depths of diffusion layers (requirement $0.25 \mathrm{~mm}-0.35 \mathrm{~mm}$ ). In addition to the structural and mechanical properties of the resulting layers, knowledge about the study of the change in surface texture and dimensional accuracy of samples after the nitriding process is also given.

\section{Materials and methods}

Two steels, $42 \mathrm{CrMo} 4$ and $34 \mathrm{CrNiMo6}$, were selected for the analysis of structural and mechanical properties. $42 \mathrm{CrMo} 4$ steel is a low-alloy, noble, Cr-Mo steel for tempering and surface hardening. The dominant element that forms the properties of the diffusion layer is $\mathrm{Cr}$ and Mo. 34CrNiMo6 steel is a mediumalloy, noble, Cr-Ni-Mo steel for tempering, for highly stressed parts with the requirement of the highest toughness. It is characterized by high values of fatigue limit in alternating and combined stress modes. Diffusion layers are characterized by lower hardness and higher plasticity.

Chemical composition analysis was performed using a Q4 Tasman spark optical emission spectrometer. The produced experimental samples were heat treated in a laboratory furnace LAC L70V. Chemical- heat treatment processes were performed in a Rübig PN 100/180 device (in the case of plasma nitriding) and in a Nitrex 80/200 device (in the case of gas nitriding). To assess changes in the structure of the surface layer, before and after the chemical-thermal treatment processes, observations were performed using an inverted opto-digital metallographic microscope Olympus DSX500, at a magnification of 500x. The structure was observed in polarized light in a cross section of a metallographic sample perpendicular to the formed surface.The surface hardness was measured on an instrumented Zwick ZHU 2.5 hardness tester, with a load of $10 \mathrm{~kg}$ (HV10). The mechanical properties of the surface layers and the depths of the diffusion layers were measured using microhardness curves on an automated Leco LM247AT microhardness tester, with a load of $100 \mathrm{~g}$ (HV0.1). The bending impact test was performed on an instrumented Zwick Roell RKP 450 impact hammer with a nominal energy of $300 \mathrm{~J}$, at a temperature of $21^{\circ} \mathrm{C}$. Measurements of dimensional change of experimental samples after chemical-heat treatment were performed on a 3D CNC coordinate machine Werth ScopeCheck ${ }^{\circledR S}$ and evaluated by WinWerth ${ }^{\circledR} 8$ software. Surface texture parameters (roughness) were measured by the noncontact method with a coherent correlation interferometer Talysurf CCI Lite. The obtained data were analyzed using MountainsLab Premium 8 software.

\section{Experimental Section}

First of all, the chemical composition of selected steels was evaluated. The results are shown in Table 1.

Tab. 1 Chemical composition of evaluated steels (wt. \%)

\begin{tabular}{|c|c|c|c|c|c|c|c|}
\hline $\mathbf{C}$ & Mn & Si & Cr & Ni & Mo & P & S \\
\hline \multicolumn{7}{|c|}{ 42CrMo4 - Standard } \\
\hline $0.38-0.45$ & $0.50-0.80$ & $0.17-0.37$ & $0.90-1.20$ & Max. 0.50 & $0.15-0.30$ & Max. 0.035 & Max. 0.035 \\
\hline \multicolumn{8}{|c|}{ 42 CrMo4 - Q4 Tasman } \\
\hline 0.39 & 0.82 & 0.31 & 1.09 & 0.06 & 0.19 & 0.011 & 0.015 \\
\hline \multicolumn{8}{|c|}{ 34CrNiMo6 - Standard } \\
\hline $0.32-0.40$ & $0.50-0.80$ & $0.15-0.40$ & $1.30-1.70$ & $1.30-1.70$ & $0.20-0.30$ & Max. 0.035 & Max. 0.035 \\
\hline \multicolumn{7}{|c|}{ 34CrNiMo6 - Q4 Tasman } \\
\hline 0.36 & 0.76 & 0.25 & 1.65 & 1.94 & 0.20 & 0.019 & 0.034 \\
\hline
\end{tabular}

Experimental samples measuring $90 \mathrm{~mm} \times 30 \mathrm{~mm}$ x $20 \mathrm{~mm}$ were made of steel (see Fig. 1). From each steel, 5 pieces of specimens (prisms) and 10 pieces of test specimens were made for the impact test in bending with a V-notch of $2 \mathrm{~mm}$ depth (specimen dimensions $10 \mathrm{~mm} \times 10 \mathrm{~mm} \times 55 \mathrm{~mm}$, according to ISO 148-1 [13]). The sample surfaces were ground on a BPH 20 NA planar horizontal grinder, Norton 3SG46JVS grinding wheel measuring $200 \mathrm{~mm} \times 20$ $\mathrm{mm} \times 32 \mathrm{~mm}$, spindle speed $\mathrm{n}=2400 \mathrm{rpm} \cdot \mathrm{min}^{-1}$, cutting depth $\mathrm{h}=0.03 \mathrm{~mm}$, grinding wheel width $\mathrm{b}=$ $20 \mathrm{~mm}$. The surface roughness requirement was $\mathrm{Ra}=$
$1.6 \mu \mathrm{m}$. TRIM MicroSol 515 semi-synthetic cutting fluid was used as a cooling medium during machining. The $\mathrm{V}$-notches on the test specimens for the bending impact test were made on a Sodick AQ 400L wire cutter.

The samples were normalized annealed, hardened and tempered, the samples thus prepared were futher nitrided. The parameters of heat treatment and chemical-heat treatment processes are documented in Table 2.

Similar structural factors, increasing the hardness 
of the surface, apply their effect to the basic mechanical characteristics - yield strength, tensile strength and fatigue limit [14]. This means that as the hardness of the surface layer formed by the chemical-heat treatment process increases, its fatigue limit increases. From the evaluated steels, all samples in the tempered state were selected for measurement, which were further analyzed after the chemical-thermal treatment process.

Dimensional changes were evaluated by a touch sensor. The distances between the foreheads of the sample were measured, the surfaces of which were ground and the distance according to the drawing was prescribed at $90 \mathrm{~mm}$. The measurement conditions are shown in Table 3.

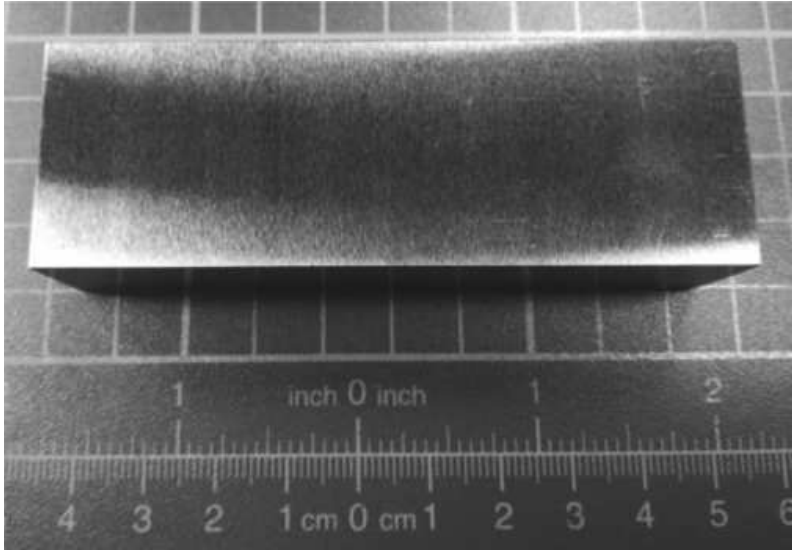

Fig. 1 Experimental sample

Tab. 2 Parameters of heat treatment and chemical-heat treatment

\begin{tabular}{|c|c|c|c|c|c|}
\hline Steel & $\begin{array}{l}\text { Normalization } \\
\text { annealing }\end{array}$ & Hardening & Tempering & Plasma nitriding & Gas nitriding \\
\hline 42CrMo4 & $\begin{array}{l}860^{\circ} \mathrm{C} / 45 \mathrm{~min} / \\
\text { air }\end{array}$ & $\begin{array}{l}840^{\circ} \mathrm{C} / 45 \\
\mathrm{~min} / \text { water }\end{array}$ & $\begin{array}{l}600^{\circ} \mathrm{C} / 100 \\
\min / \text { water }\end{array}$ & \multirow{2}{*}{$\begin{array}{l}520^{\circ} \mathrm{C} / 14 \text { hours } \\
/ 1 \mathrm{H}_{2}: 3 \mathrm{~N}_{2}\end{array}$} & \multirow{2}{*}{$\begin{array}{l}530{ }^{\circ} \mathrm{C} / 7 \\
\text { hours / } \\
\mathrm{NH}_{3} / \mathrm{N}_{2} / \mathrm{H}_{2}\end{array}$} \\
\hline 34CrNiMo6 & $\begin{array}{l}870{ }^{\circ} \mathrm{C} / 45 \mathrm{~min} / \\
\text { air }\end{array}$ & $\begin{array}{l}850^{\circ} \mathrm{C} / 45 \\
\min / \text { oil }\end{array}$ & $\begin{array}{l}600{ }^{\circ} \mathrm{C} / 100 \\
\mathrm{~min} / \text { water }\end{array}$ & & \\
\hline
\end{tabular}

Tab. 3 Conditions for measuring the dimensional change

\begin{tabular}{|c|c|c|c|c|}
\hline $\begin{array}{c}\text { Measured area } \\
(\mathbf{m m})\end{array}$ & $\begin{array}{c}\text { Number of scan- } \\
\text { ned points of one } \\
\text { surface }\end{array}$ & Temperature $\left({ }^{\circ} \mathbf{C}\right)$ & $\begin{array}{c}\text { Max. error E1 for } \\
\mathbf{L}=\mathbf{9 0} \mathbf{~ m m}(\boldsymbol{\mu m})\end{array}$ & $\begin{array}{c}\text { Uncertainty for } \\
\mathbf{L}=\mathbf{9 0} \mathbf{~ m m} \\
(\mathbf{m m})\end{array}$ \\
\hline $27 \times 17$ & 25 & $22 \pm 1$ & 3.25 & \pm 0.001 \\
\hline
\end{tabular}

The surface texture was measured on the ground surfaces of foreheads of the experimental samples, always in the middle part of the machined surface of the sample. The same place was scanned even after nitriding. One sample of a given series was always measured. The conditions for measuring the surface texture are documented in Table 4. The measurement conditions were determined in accordance with the standard ISO 4288 [15].

Tab. 4 Conditions for measuring the surface texture of experimental samples

\begin{tabular}{|c|c|c|c|c|c|}
\hline Measured area & End-effect & $\begin{array}{c}\text { Evaluated area } \\
\text { (3D) }\end{array}$ & $\begin{array}{c}\text { Evaluated } \\
\text { length (2D) }\end{array}$ & Cut-off & Filtration \\
\hline $2.5 \mathrm{~mm} \times 2.5 \mathrm{~mm}$ & $64 \%$ & $1.5 \mathrm{~mm} \times 1.5 \mathrm{~mm}$ & $4 \mathrm{~mm}$ & $0.8 \mathrm{~mm}$ & Gauss \\
\hline
\end{tabular}

\section{Results and Discussion}

\subsection{Structure of Nitrided Layers}

The phase composition of the surface layer in the nitrided component can be derived from the isothermal section of the ternary diagram Fe-C-N. With regard to the present phases, it is divided into two basic areas [16], [17] and [18]:

- Purely nitride region (white layer), formed by nitrides, resp. carbonitrides of type $\varepsilon\left(\mathrm{Fe}_{2}\right.$ $\left.{ }_{3} \mathrm{~N}\right)$ and $\gamma^{\prime}\left(\mathrm{Fe}_{4} \mathrm{~N}\right)$ of iron and alloying elements. Only exceptionally is a nitride of type $\xi\left(\mathrm{Fe}_{2} \mathrm{~N}\right)$ present. Its actual structure is influ- enced by the technology of the saturating process and the composition of the steel. A common phenomenon is the porosity of the nitrided layer due to the instability of nitrides, the release of atomic nitrogen and exothermic reactions during its fusion.

- Diffusion layer, the structure of which consists of ferrite (nitrogen's ferrite) and nitrides (carbonitrides) of Fe and alloying elements, or carbides. Nitride formation is essentially a precipitation process from nitrogen supersaturated ferrite. The consequence of its time- 
dependent course in several stages is the formation of both coherent and incoherent nitrides. The resulting layer structure depends on the nitriding conditions and the type of alloys in the steel.

The structure of 42CrMo4 steel after tempering consists of tempered martensite and sorbite (Fig. 2). Plasma nitriding led to the formation of a tempered martensite structure, which turns into tempered martensite and sorbite towards the core of the material.
The diffusion layer became visible by etching the samples. A continuous white layer of nitrides formed on the steel surface. The structure of tempered martensite and sorbite was formed in the surface layer after the gas nitriding process. Furthermore, a uniform, thick, white layer of nitrides was formed. The diffusion layer, visible by etching, reached a smaller depth than in the case of plasma nitriding.

The 34CrNiMo6 heat-treated steel is characterized by the structure of tempered martensite and sorbite (Fig. 3).

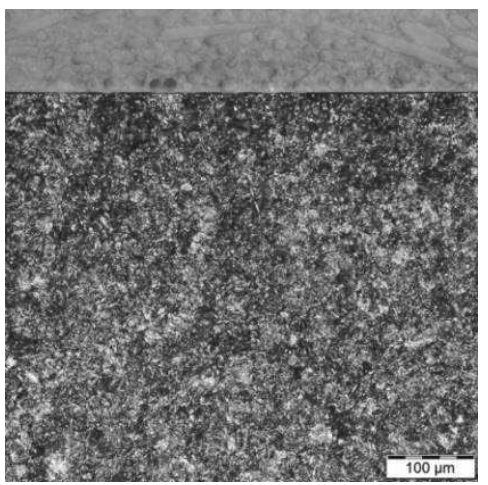

Ground

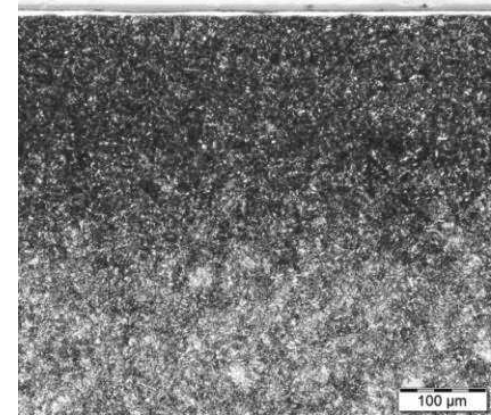

Plasma nitriding

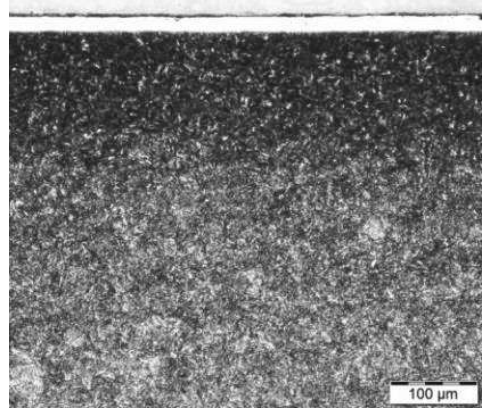

Nitriding in gas

Fig. 2 Structure of 42CrMo4 steel, etchant NITAL 2\%, magnified 500x

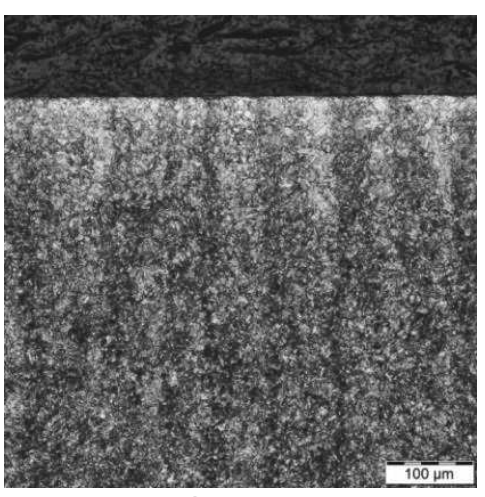

Ground

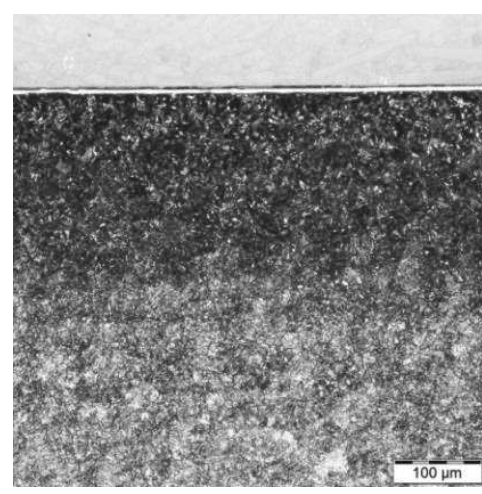

Plasma nitriding

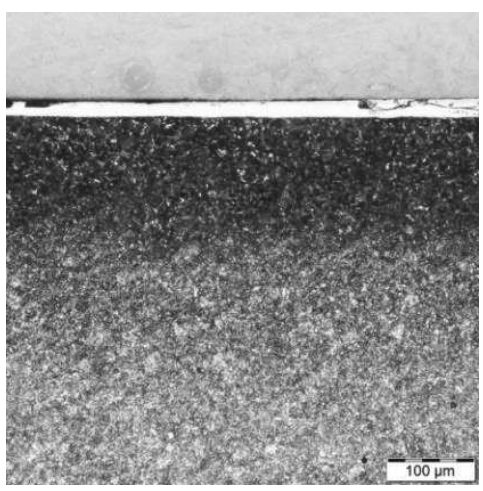

Nitriding in gas

Fig. 3 Structure of 34CrNiMo6 steel, etchant NITAL 2\%, magnified $500 x$

The ground surface shows a linearity of the structure and an enlargement of the grains in the surface layer, which can be caused by the thermal effect of the surface during grinding. After the plasma nitriding process, a structure formed by tempered martensite and sorbite can be observed. A compact white layer of nitrides formed on the steel surface. The process of nitriding in gas is again characterized by the structure of tempered martensite and sorbite, but with a significantly thicker white layer of nitrides on the steel surface. The etch-enhanced diffusion layer reaches a shallower depth than in the case of plasma nitrided steel.

\subsection{Hardness of Nitrided Layer}

As already mentioned the basic property of a purely nitride layer - hardness, depends on the type and composition of the phases present, eg $\mathrm{Fe}_{4}(\mathrm{NC})$ has a hardness $\mathrm{HV} \sim 600$, but $(\mathrm{FeAl})_{4}(\mathrm{CN})$ up to 1200 HV. Further increases are provided by macroscopic internal stresses, caused by an increase in the volume (up to $5 \%$ ) of the white layer due to differences in the parameters of the crystal lattices $\alpha, \gamma^{\prime}$ and $\varepsilon$. The results of the measurement of the hardness of the surface layer of nitrided steels are given in Table 5 . 
Tab. 5 Results of surface hardness measurement of experimental samples (HV10)

\begin{tabular}{|c|c|c|c|c|c|}
\hline \multirow{2}{*}{ Steel } & \multicolumn{5}{|c|}{ Heat treatment and chemical-heat treatment process } \\
\cline { 2 - 6 } & Tempered & $\begin{array}{c}\text { Plasma nitri- } \\
\text { ded }\end{array}$ & Growth & Nitrided in gas & Growth \\
\hline 42 CrMo4 & $298 \pm 5$ & $665 \pm 32$ & $\begin{array}{c}+367 \\
(+123.2 \%)\end{array}$ & $705 \pm 5$ & $\begin{array}{c}+407 \\
(+136.6 \%)\end{array}$ \\
\hline 34 CrNiMo6 & $303 \pm 9$ & $613 \pm 28$ & $\begin{array}{c}+310 \\
(+102.3 \%)\end{array}$ & $671 \pm 49$ & $\begin{array}{c}+368 \\
(+121.5 \%)\end{array}$ \\
\hline
\end{tabular}

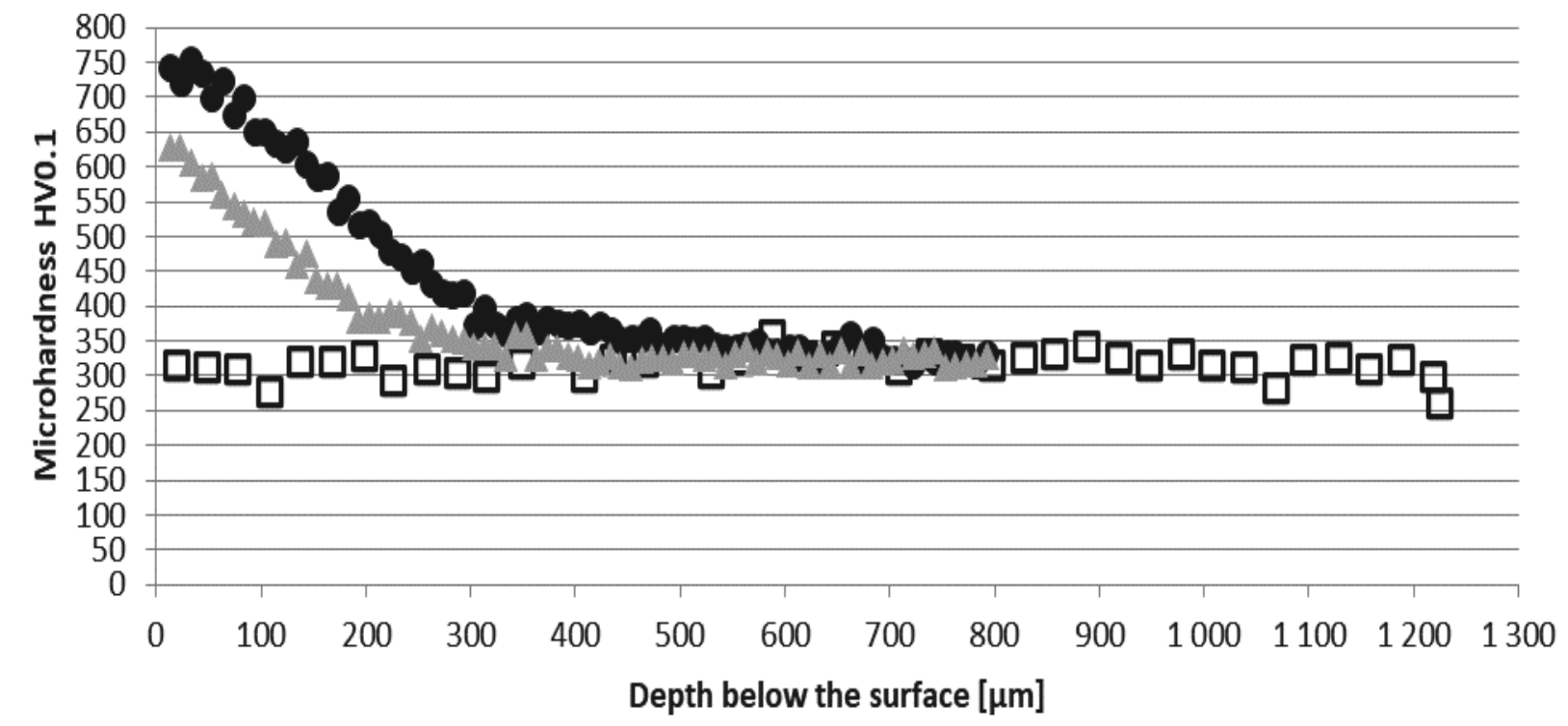

QGround $\bullet$ Plasma nitriding $\triangle$ Gas nitriding

Fig. 4 Microhardness curves depending on the distance from the ground surface of 42CrMo4 steel after nitriding processes

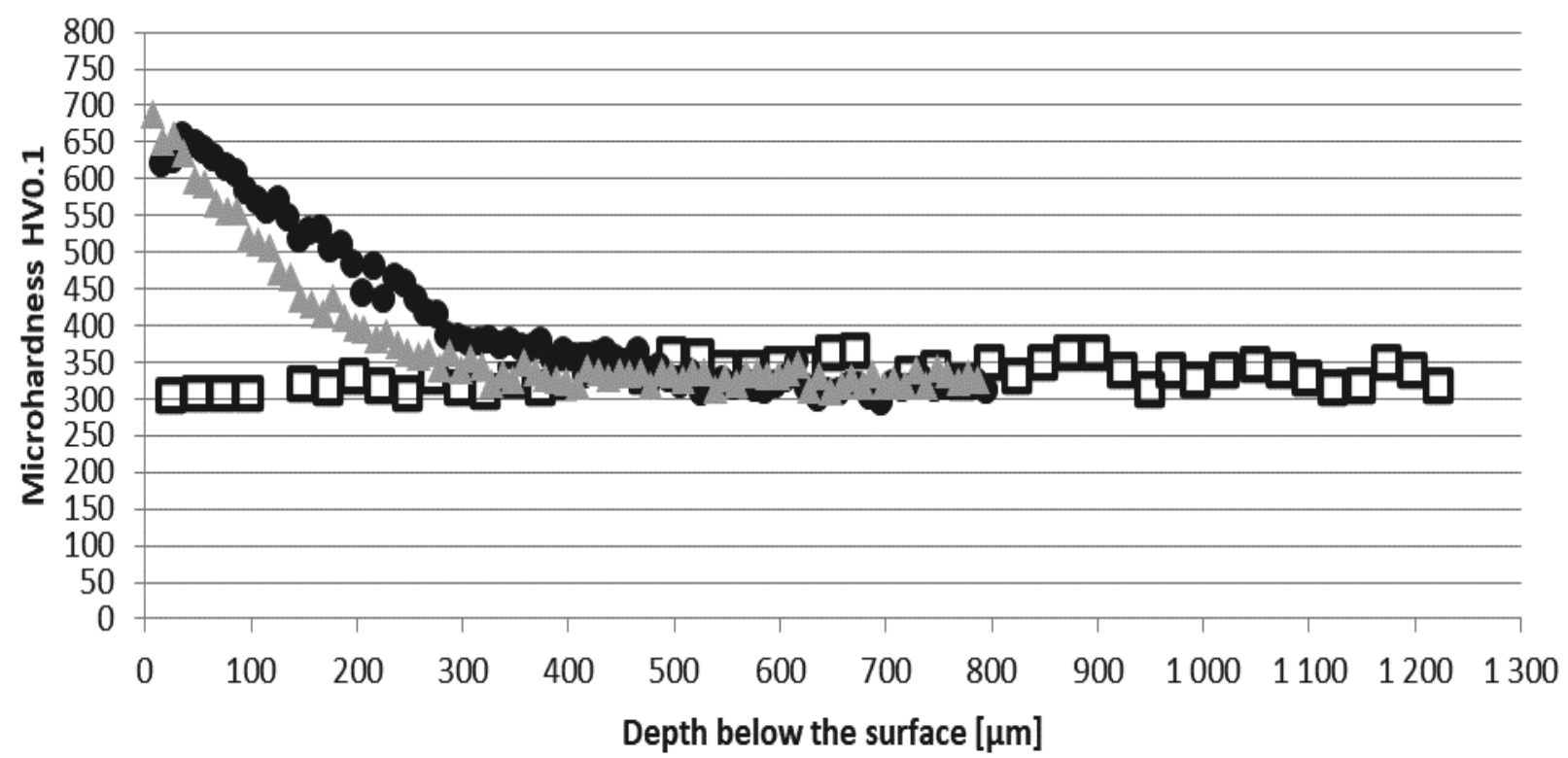

口Ground $\bullet$ Plasma nitriding $\Delta$ Gas nitriding

Fig. 5 Microhardness curves depending on the distance from the ground surface of 34CrNiMo6 steel after nitriding processes 
Tab. 6 Results of surface hardness, microhardness and white layer thickness measurements

\begin{tabular}{|c|c|c|c|c|c|c|}
\hline \multirow[b]{2}{*}{ Steel } & \multirow[b]{2}{*}{ Condition } & \multirow{2}{*}{$\begin{array}{c}\text { Surface } \\
\text { hardness } \\
\text { HV10 }\end{array}$} & \multicolumn{2}{|c|}{ Microhardness HV0.1 } & \multirow{2}{*}{$\begin{array}{c}\text { Depth of } \\
\text { diffusion } \\
\text { layer } \\
(\mathrm{mm})\end{array}$} & \multirow{2}{*}{$\begin{array}{c}\text { White layer } \\
\text { thickness } \\
\qquad(\mu \mathrm{m})\end{array}$} \\
\hline & & & $\begin{array}{l}\text { Under sur- } \\
\text { face }\end{array}$ & $\begin{array}{l}\text { Core of ma- } \\
\text { terial }\end{array}$ & & \\
\hline \multirow{3}{*}{ 42CrMo4 } & Tempered & 298 & 315 & 311 & - & - \\
\hline & Plasma nitrided & 665 & 753 & 331 & 0.319 & 6.4 \\
\hline & Nitrided in gas & 705 & 637 & 323 & 0.224 & 18.4 \\
\hline \multirow{3}{*}{ 34CrNiMo6 } & Tempered & 303 & 312 & 301 & - & - \\
\hline & Plasma nitrided & 613 & 557 & 322 & 0.342 & 4.4 \\
\hline & Nitrided in gas & 671 & 670 & 322 & 0.234 & 18.6 \\
\hline
\end{tabular}

The course of hardness in the nitrided layer is approximated for common technical use by a continuous curve. A more thorough measurement of the course of microhardness of nitrided samples is documented in Fig. 4 and Fig. 5. Microhardenss was measured in accordace with the standard ISO 18203:2016 [19].

A summary of the results of measurements of surface hardness, microhardness of the surface layer, depth of the diffusion layer and thickness of the white layer of the evaluated steels is documented in Table 6 .

Nitriding processes in both steels led to a more than twofold increase in surface hardness. The same results were obtained in the case of microhardness of the surface layer. Greater depths of diffusion layers were achieved after plasma nitriding, on the contrary, nitriding in gas led to the formation of approximately quadruple the thickness of the white layer.

\subsection{Notch Toughness}

The bending impact test was performed in accordance with the standards ISO 148-1 [13] and ISO 1483 [20]. The results of the impact bending test were evaluated in the TestXpert II program by analyzing the force-deflection curves, the area of which in the coordinate system of the $X$ and $Y$ axes characterizes the consumed work. The results of the notch toughness are given in Table 7. It is clear from the results that the nitriding process leads to a reduction in the value of the notch toughness. A larger decrease was recorded after plasma nitriding, a more significant decrease was observed for 42CrMo4 steel.

Tab. 7 Results of notch toughness

\begin{tabular}{|c|c|c|c|}
\hline \multirow{2}{*}{ Steel } & Process & $\begin{array}{c}\text { The share of ductile } \\
\text { fracture (\%) }\end{array}$ & KCV (J) \\
\hline \multirow{3}{*}{42 CrMo4 } & Ground & 72 & $136.9 \pm 17.0$ \\
\cline { 2 - 4 } & Plasma nitrided & 63 & $95.4 \pm 0.8$ \\
\cline { 2 - 4 } & Nitrided in gas & 66 & $118.8 \pm 7.4$ \\
\hline \multirow{3}{*}{34 CrNiMo6 } & Ground & 77 & $173.5 \pm 6.1$ \\
\cline { 2 - 4 } & Plasma nitrided & 64 & $151.6 \pm 6.2$ \\
\cline { 2 - 4 } & Nitrided in gas & 72 & $171.7 \pm 4.1$ \\
\hline
\end{tabular}

\subsection{Measurement of Dimension}

The values of the increase in the dimensions of the experimental samples, given in Table 8 , express the mean value of the increase from 5 measurements of 5 samples after the selected nitriding processes. These

Tab. 8 Dimensional increase values after nitriding process

\begin{tabular}{|c|c|c|c|c|c|}
\hline \multirow{2}{*}{ Steel } & \multirow{2}{*}{ Tempered } & \multicolumn{3}{|c|}{ Proces of chemical-heat treatment } \\
\cline { 2 - 6 } & $\begin{array}{c}\text { Sample size } \\
(\mathbf{m m})\end{array}$ & $\begin{array}{c}\text { Sample size } \\
(\mathbf{m m})\end{array}$ & $\begin{array}{c}\text { Increase of di- } \\
\text { mension }(\mathbf{m m})\end{array}$ & $\begin{array}{c}\text { Sample size } \\
\mathbf{( m m}\end{array}$ & $\begin{array}{c}\text { Increase of di- } \\
\text { mension }(\mathbf{m m})\end{array}$ \\
\hline 42CrMo4 & $90.046 \pm 0.001$ & $90.078 \pm 0.001$ & $0.032 \pm 0.001$ & $90.083 \pm 0.002$ & $0.037 \pm 0.002$ \\
\hline 34 CrNiMo6 & $89.974 \pm 0.001$ & $89.996 \pm 0.002$ & $0.023 \pm 0.002$ & $90.000 \pm 0.002$ & $0.026 \pm 0.002$ \\
\hline
\end{tabular}

\subsection{Evaluation of Surface Texture}

The surface texture of the experimental samples of growth values are compared with the mean value of the treated samples, which here represents the reference value 0 (zero). After nitriding, the sample dimensions increased. A larger increase can be seen after plasma nitriding in both evaluated steels.

the evaluated steels is shown in Fig. 6. After the nitriding processes, a more pronounced surface morphology can be seen, with a larger number of small, minor 
peaks on the original traces of grinding. From the point of view of texture evaluation, it can be con- cluded on the basis of the parameter Sa that the nitriding of these steels led to a slight reduction of the surface roughness.

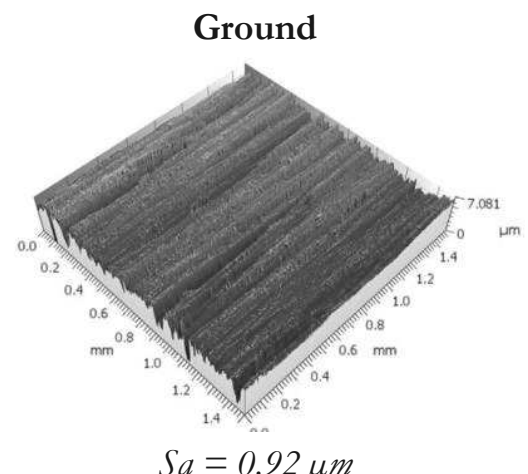

$S_{a}=0.92 \mu \mathrm{m}$

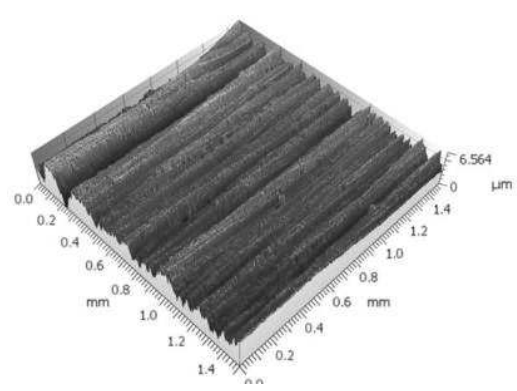

$S_{a}=0.94 \mu \mathrm{m}$

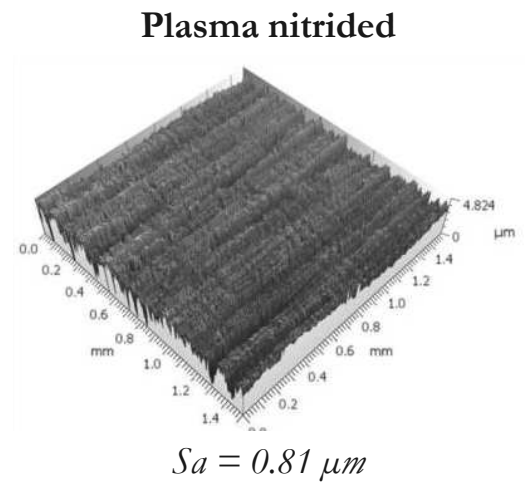

42CrMo4

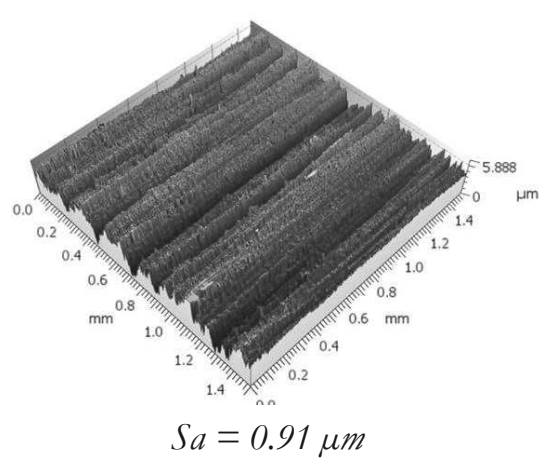

34CrNiMo6
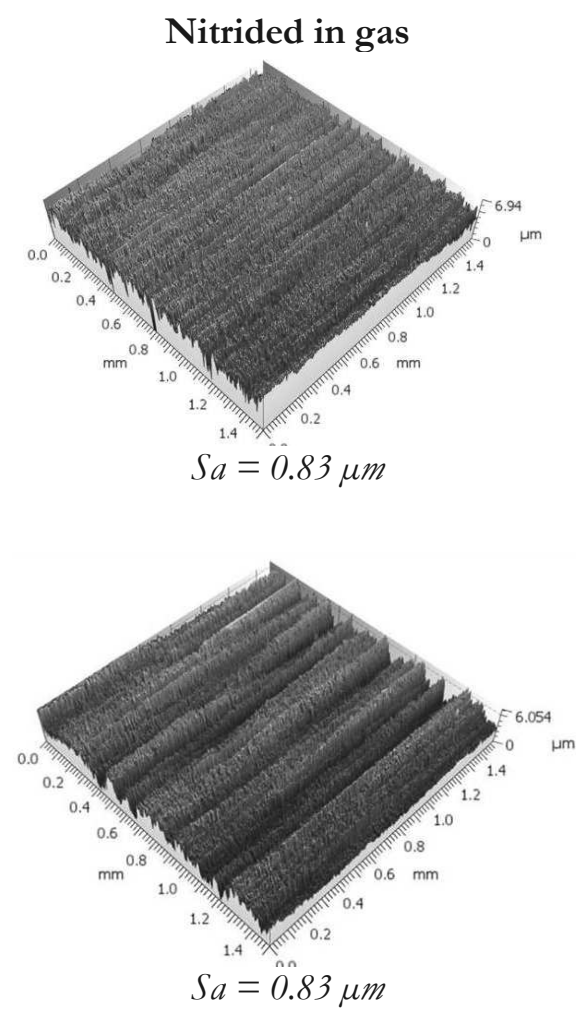

Fig. 6 Surface texture of experimental samples

The achieved results of the analysis of mechanical properties confirmed the benefit of nitriding processes, which lead to an increase in surface hardness and are in line with the results obtained in [21], [22], [23] and [24]. Notch toughness analysis confirmed the conclusions presented in [25], [26] and [27], that the nitrided layer in the notch roots probably simulates the critical size of the crack formed in the notch root of the non-nitrided sample, leading to reduced notch toughness values. The change of dimensions of experimental samples after nitriding processes has been published, for example, in [28] and [29]. It has been confirmed that nitriding processes lead to an increase in component dimensions. The reduction of the values of the 3D area parameter Sa, after the nitriding processes, can be considered in the case of the evaluated steels as new, hitherto unpublished results, because diffusion processes normally lead to deterioration of surface roughness [30], [31]. Together with the analysis of the structure and its influence on the material characteristics, the results of the presented measurements confirmed the suitability of nitriding processes to increase the useful properties of structural steels, both in terms of mechanical properties and surface texture. However, the lower service life of the nitrided members may be due to higher cyclic loading amplitudes, because the presence of the nitrided layer leads to a more desirable initiation of fatigue failure. A negative phenomenon of nitriding is also the increase in the dimensions of the parts, which must be taken into account during finishing machining operations.

\section{Conclusion}

The superposition of the strengthening effects of complex carbonitrides of coherent and incoherent character and internal stresses at both macroscopic and microscopic levels can be considered as the main causes of increased hardness and strength of nitrided parts. Conversely, a substantially higher fatigue crack propagation rate in the nitrided layer and a lower fracture toughness value may mean a reduction in component life at higher stress amplitudes. Dimensional and shape changes of structural components are generally an undesirable accompanying phenomenon of chemical-heat processing processes. From a practical point of view, dimensional changes represent a minor prob$\mathrm{lem}$, and if their size is in a sufficiently narrow interval (small scatter of values), they can be prevented, for example, by setting corrections during machining. Closely related to changes in dimensions is the issue of changing the texture (roughness) of the surface of components after chemical-heatl treatment processes. 
A similar microstructure containing sorbite and tempered martensite was achieved in both evaluated steels. Nitriding processes have led to more than a twofold increase in surface hardness, compared to ground surfaces. Higher surface hardness values were achieved for $42 \mathrm{CrMo} 4$ steel. Higher surface hardness was obtained after the gas nitriding process. The plasma nitriding process led to greater diffusion layer depths than the gas nitriding process, which is due, among other things, to twice the process time. Larger values of diffusion layers were measured for 34CrNiMo6 steel. However, more than three times thicker white layers were observed after the gas nitriding process. The thicknesses of the white layers reached similar values in both steels. In terms of evaluation of notch toughness, both nitriding processes led to its reduction. A larger reduction was observed after the plasma nitriding process and in $42 \mathrm{CrMo} 4$ steel. Nitriding in gas led to larger dimensional changes compared to plasma nitriding. Here, the greater thickness of the white layer may play a role, which causes an increase in volume and also the internal stress in the surface layer of steel. Significantly higher dimensional changes were recorded for $42 \mathrm{CrMo} 4$ steel. In both steels, the decrease of the 3D parameter of the area Sa was measured, the decrease was not somewhat significant (around 10\%), but it can be said that the nitriding processes improved the surface roughness. The obtained results confirmed the suitability of the evaluated steels for nitriding processes, which lead to an increase in useful properties (increase in hardness). Furthermore, it was shown that the evaluated steels did not deteriorate the surface roughness, which is characteristic of diffusion processes. The disadvantage of the selected processes is the reduction of the notch toughness of the evaluated steels, which must be taken into account in the design stage of the components. The increase in dimensions after nitriding processes must be taken into account in the finishing operations to ensure the required dimensional accuracy of the part, within the required tolerance.

\section{Acknowledgements}

The work presented in this paper has been supported by the specific research project 2020 "SV20-216" at the Department of Mechanical Engineering, University of Defense in Brno and the Project for the Development of the Organization "DZRO K201".

\section{References}

[1] SUBBIAH, R., PORAS, A., BABU, K.R., GANDHI, M.M., SREE, K.R., NAVEEN, CH. (2020). Materialstoday: Proceedings, Vol. 26, No. 2, pp. 2977-2982.
[2] SINGH, S.K., NAVEEN, CH., SAI, Y.V., SATISH, Y.V., BANDHAVI, CH., SUBBIAH, R. (2019). Materialstoday: Proceedings, Vol. 18, No. 7, pp. 2717-2722.

[3] WANG, Y., YANG, Y., YANG, H., ZHANG, M., MA, S., QIAO, J. (2018). Materials Chemistry and Physics, Vol. 210, pp. 233-239.

[4] ZHANG, F., YAN, M., HE, J., YIN, F. (2017). Ceramics International, Vol. 43, No. 14, pp. 10832-10839.

[5] GHASEMI, M.H., GHASEMI, B., SEMNAMI, H.R.M. (2019). Diamond and Related Materials, Vol. 93, pp. 8-15.

[6] MAJERÍK, J., BARÉNYI, I., SEDLÁK, J., KUSENDA, R., ECKERT, M. (2020). Manufacturing Technology, Vol. 20, No. 1, pp. 72-77.

[7] JI, Y.J., KIM, K.S., KIM, K.H., ELLINGBOE, A.R., YEOM, G.Y. (2020). Applied Surface Science, Vol. 506.

[8] SHEN, H., WANG, L. (2020). Surface and Coatings Technology, Vol. 403.

[9] MIČIETOVÁ, A., URÍČEK, J., HEIM, D., ČILLIAKOVÁ, M., NESLUŠAN, M. (2018). Manufacturing Technology, Vol. 18, No. 6, pp. 962966.

[10] KRBAŤA, M., MAJERÍK, J., BARÉNYI, I., MIKUŠOVÁ, I., KUSMIČ, D. (2019). Manufacturing Technology, Vol. 19, No. 9, pp. 238-242.

[11] GRONOSTAJSKI, Z., WIDOMSKI, P., KASZUBA, M., ZWIERZCHOWSKI, M., POLAK, S., PIECHOWICZ, L., KOWALSKA, J., DLUGOZIMA, M. (2020). Journal of Manufacturing Processes, Vol. 52, pp. 247262.

[12] DVORAK, I., HANAK, J. (1995). Materials and Technologies in the Production of Special Equipment, Vol. III, pp. 19-28.

[13] ISO 148-1 Metallic materials - Charpy (Vnotch and U-notch) pendulum impact test method for determining the energy absorbed in an impact test of metallic materials.

[14] STUDENY, Z., DOBROCKY, D., POKORNY, Z. (2017). Manufacturing Technology, Vol. 17, No. 1, pp. 94-99.

[15] ISO 4288 Geometrical Product Specifications (GPS) - Surface texture: Profile method - Rules and procedures for the assessment of surface texture. 
[16] PENG, T., CHEN. Y., LIU, X., WU, M., LU, Y., HU, J. (2020). Surface and Coatings Technology, In Press.

[17] FERNANDES, F.A.P., HECK, S.C., PICONE, C.A., CASTELETTI, L.C. (2020). Surface and Coatings Technology, Vol. 381.

[18] CHE, H.L., TONG, S., WANG, K.S., LEI, M.K., SOMERS, M.A.J. (2019). Acta Materialia, Vol. 177, pp. 35-45.

[19] ISO 18203:2016 Steel - Determination of the thickness of surface-hardened layers, Technical Committee: ISO/TC17/SC17, 2016.

[20] ISO 148-3 Mettalic materials - Charpy pendulum impact test - Part 3: Preparation and characterization of Charpy V-notch test pieces for indirect verification of pendulum impact machines.

[21] PENG, T., CHEN, Y., LIU, X., WU, M., LU, Y., HU, J. (2020). Surface and Coatings Technology, Vol. 403, pp. 1-5.

[22] WEBER, T., de WIT, L., SARIS, F.W., KÖNIGER, A., RAUSCHENBACH, B., WOLF, G.K., KRAUSS, S. (1995). Materials Science and Ingeneering, Vol. A199, pp. 205-210.

[23] PROCHÁZKA, J., POKORNÝ, Z., NGUYEN, H.CH. (2020). ECS Transactions, Vol. 99, No. 1, pp. 255-263.
[24] JOSKA, Z., POKORNÝ, Z., KADLEC, J., STUDENÝ, Z., SVOBODA, E. (2020). Acta Polytechnica CTU Proceedings, Vol. 27, pp. 53-56.

[25] WIPPLER, J., FETT, T., BÖHLKE, T., HOFFMANN, M.J. (2013). Journal of European Ceramic Society, Vol. 33, No. 10, pp. 1729-1736.

[26] DOBROCKÝ, D., KUSMIČ, D. (2015). Metal 2015, 24th International Conference on Metallurgy and Materials, pp. 132-140.

[27] FIRRAO, D., UGUES, D. (2005). Materials Science and Engineering: A, Vol. 409, No. 1-2, pp. 309-316.

[28] PYE, D. (2003). Practical Nitriding and Ferritic Nitrocarburizing, pp. 119-122. ASM International, Ohio. ISBN 0-87170-791-8.

[29] DOBROCKÝ, D., POKORNÝ, Z., STUDENÝ, Z., JOSKA, Z., PROCHÁZKA, J., SVOBODA. E. (2020). Metal 2020, 29th International Conference on Metallurgy and Materials, pp. 617-626.

[30] LI, G., LIANG, Y., SUN, H., CAO, Y. (2020). Surface and Coatings Technology, Vol. 384, pp. 1-11.

[31] FILHO, D. dos S., TSCHIPTSCHIN, A.P., GOLDENSTEIN, H. (2020). Surface and Coatings Technology, Vol. 404, pp. 1-11. 